\title{
Pengelolaan Keuangan Kelompok Usaha Mikro, Kecil dan Menengah Berbasis Wanita
}

\author{
Sri Rahayu, Yudi, Wiwiek Tiswiyanti,Rahayu \\ Dosen Jurusan Akuntansi FEB UNJA \\ Email: sri_rahayu@unja.ac.id
}

\begin{abstract}
Abstrak: Artikel ini bertujuan untuk mengungkap pentingnya pengelolaan keuangan bagi kelompok Usaha Mikro, Kecil dan Menengah (UMKM) berbasis wanita. Artikel ini disusun berdasarkan pengalaman tim melakukan kegiatan pengabdian dan pembinaan terhadap usaha peningkatan pendapatan keluarga (UP2K) pada tiga tahun terakhir. Pengabdian terakhir yang dilakukan terkait tema adalah Pengabdian Skim Bina Desa yang dilaksanakan Desa Mendalo darat dan Desa Mendalo Indah. Salah satu program yang terus dikembangkan oleh Tim PKK kedua desa tersebut adalah pengembangan UP2K. Walaupun relatif baru bagi pengurus, pengurus harus melakukan pengelolaan keuangan dana UP2K dengan baik. Kendala utama yang menyebabkan lambannya perkembangan UP2K adalah keterbatasan anggaran, rendahnya kompetensi SDM dan data UMKM yang kurang tersedia. Hal ini dapat menurunkan kepercayaan anggota kepada pengurus. Kegiatan pengabdian telah dilaksanakan dengan lancar.Pengelolaan keuangan UP2K melingkupi administrasi keuangan kelompok khusus, Administrasi keuangan kelompok pelaksana, Laporan Pertanggungjawaban Periodik (Triwulan) dan Laporan Pertanggungjawaban Tahunan.
\end{abstract}

Kata Kunci: Akuntabilitas, Transparansi, Kelompok Khusus, Kelompok Pelaksana

\section{PENDAHULUAN}

Keluarga merupakan gabungan dari dua atau lebih dari dua pribadi yang berkumpul karena hubungan darah, hubungan perkawinan atau pengangkatan, di hidupnya dalam satu rumah tangga, berinteraksi satu sama lain dan di dalam perannya masing-masing dan menciptakan serta mempertahankan suatu kebudayaan (Baron \&Bryne, 2003). Keluarga adalah unit terkecil dari masyarakat yang terdiri atas kepala keluarga dan beberapa orang yang terkumpul dan tinggal di suatu tempat di bawah suatu atap dalam keadaan saling ketergantungan.Keluarga inti yang terdiri dari ayah, ibu dan anak menjadi bagian dari lembaga sosial masyarakat.

Setiap anggota keluarga memiliki peranan masing-masing. Ayah sebagai kepala keluarga memiliki peran sebagai pencari nafkah, pendidik, pelindung dan pemberi rasa aman. Selain sebagai kepala keluarga, ayah juga sebagai anggota dari kelompok sosialnya serta sebagai anggota masyarakat dari lingkungannya. Istri dan ibu dari anak-anaknya, ibu mempunyai peranan untuk mengasuh dan mendidik anak, mengurus rumah tangga, pelindung dan sebagai salah satu kelompok dari peranan sosialnya serta sebagai anggota masyarakat dari lingkungannya. Di samping itu juga ibu juga dapat membantu ayah sebagai pencari nafkah tambahan dalam keluarganya. Anak-anak melaksanakan peranan sesuai tingkat perkembangannya baik fisik, mental, sosial, dan spiritual.

Ibu dapat bergabung dalam kelompok sosial di masyarakat untuk saling membantu dan bekerjasama untuk meningkatkan kesejahteraan keluarga. Salah satu kelompok sosial tersebut yaitu Unit Peningkatan Pendapatan Keluarga (UP2K) yang ada pada tingkat kelurahan atau RT tempat tinggalnya. UP2K merupakan kelompok masyarakat yang dibentuk dengan tujuan membina ibu-ibu pada kelompok masyarakat tertentu dengan tujuan untuk meningkatkan pendapatan keluarga anggotanya. UP2K berada di bawah binaan organisasi Pembinaan Kesejahteraan Keluarga (PKK) setempat.

Segala kegiatan ekonomi pada UP2K diusahakan oleh keluarga, baik, secara perorangan maupun kelompok, yang modalnya bersumber dari swadaya masyarakat, bantuan 
pemerintah, bantuan luar negeri, swasta, serta sumber lain yang sah dan tidak mengikat. UP2K punya tujuan meningkatkan usaha ekonomi keluarga yaitu suatu bentuk kegiatan usaha yang dilakukan oleh keluarga, bertujuan meningkatkan pendapatan keluarga dalam rangka mewujudkan kesejahteraan keluarga. UP2K bergerak untuk mengembangkan usaha ekonomi produktif yang dapat mengembangkan lapangan usaha yang didukung oleh potensi, ketersediaan bahan baku dan teknologi lokal.

Pengelolaan UP2K memegang prinsip keterbukaan dalam perencanaan, pelaksanaan dan pengelolaan usaha, Tertib administrasi dalam pengelolaan usaha, pendayagunaan potensi dan teknologi lokal dan pembuatan laporan secara berkala (per triwulan dan tahunan) (BPMM DIY, 2017). UP2K merupakan binaan PKK secara berjenjang mulai dari tingkat desa sampai secara nasional. Pada setiap desa, minimal terdiri dari satu kelompok khusus (Poksus) yang berada di tingkat desa dan beberapa kelompok pelaksana (ada tingkat RT).

Kabupaten Muaro Jambi terdiri dari 11 kecamatan dan 150 desa (muarojambikab.go.id). Berdasarkan hasil wawancara dengan salah satu pengurus PKK Tingkat Kabupaten Muaro Jambi pada tanggal 22 Februari 2018, diperoleh informasi UP2K binaan tersebar di seluruh desa di Kabupaten Muaro Jambi. Salah satu permasalahan yang dihadapi oleh UP2K hampir di seluruh daerah di Provinsi Jambi adalah kurang tertibnya administrasi dalam pengelolaan keuangan kelompok usaha. Hal ini selalu menjadi agenda diskusi yang di bahan dalam kegiatan evaluasi dan koordinasi kegiatan PKK baik tingkat Provinsi maupun Kabupaten/Kota Jambi. Proses evaluasi biasa dilakukan pada akhir tahun atau awal tahun berikutnya. Salah satu hasil evaluasi tahun padasetiap akhir tahun, persoalan lambannya perkembangan UP2K yang dikeluhkan oleh para kader juga terkait dengan sering terlambatnya laporan pertanggungjawaban dari pengurus baik pada tingkat Poksus maupun Poklak. Hal ini dikarenakan kurangnya pemahaman pengurus dan anggota UP2K dalam menyusun laporan pertanggungjawaban pengelolaan keuangan kelompoknya.

Penyusunan laporan keuangan bagi UP2K tersebut menjadi salah satu aspek penting bagi kemajuan organisasi. Dengan laporan keuangan yang memenuhi persyaratan maka proses akuntabilitas dan transparansi organisasi berjalan baik. Bahkan kesempatan bagi organisasi untuk mendapat pinjaman dari lembaga keuangan lain untuk mengembangkan usaha akan terbuka lebar. Manfaat yang dapat diberikan oleh sistem akuntansi dan pengelolaan keuangan yang baik antara lain: (1) dapat mengetahui kinerja keuangan UP2K, (2) UP2K dapat mengetahui, memilah, dan membedakan aset organisasi dan aset pengurus dan anggota, (3) dapat diketahui sumber dan penggunaan dana, (4) dapat membuat anggaran UP2K yang tepat, (5) UP2K dapat menghitung pajak, dan (6) dapat diketahui aliran uang tunai UP2K selama periode tertentu (7) laporan keuangan keuangan UP2K dapat disusun dengan baik.

Pengurus dan anggota UP2K seharusnya sadar bahwa akuntansi penting bagi organisasi mereka. Penggunaan akuntansi dalam hal inilaporan keuangan dapat mendukung kemajuan UP2K ke depan. Akuntansi juga mampu membantu merencanakan tingkat laba masa yang akan datang, sehingga kemajuan usaha dapat diperoleh serta kesejahteraan ekonomi keluarga anggota dapat meningkat. Hasilnya, perkembangan UP2K akan menjadi salah satu solusi bagi masalah perekonomian di Indonesia. Kita sadari masih banyak UP2K yang belum menyusun laporan keuangan kegiatan usahanya dengan baik. Alasannya antara lain penyusunan laporan keuangan dianggap sesuatu yang sulit dan membutuhkan pendidikan tertentu. 
Pengurus PKK dan UP2K harus memahami peran sebagai penerima amanah dari para kelompok usaha yang tergabung. Dari sudut pandang agencytheory, pengurus UP2K dapat dipandang sebagai agen sedangkan para anggota adalah prinsipal. Agen harus dapat menyampaikan pertanggungjawaban pengelola keuangan dengan baik kepada prinsipal, sehingga tidak memunculkan asimetri informasi (Halim dan Abdullah, 2006). Gap informasi yang tidak memiliki titik temu akan menjadi bom waktu bagi kehidupan organisasi. Oleh karana itu, dana desa maupun UP2K harus dikelola dengan prinsip transparan, akuntabel, partisipatif dan dilakukan dengan tertib dan disiplin anggaran (Bastian, 2015).

Pembina dan pengurus UP2K umumnya hanya memantau perkembangan usaha tanpa mengetahui perkembangan riil dari sisi keuangannya. Misalnya sebagian besar tidak mengetahui mengenai laba yang didapatkan setiap periode. Mereka bingung untuk menentukan nilai aset UP2K dalam nominal rupiah. Aset kelompok seringkali masih tercampur dengan aset pribadi, sulit untuk dipisahkan. Hal ini menyebabkan perkembangan organisasi khususnya dalam hal kinerja keuangan tidak dapat diketahui secara jelas. Dalih yang digunakan dan selalu menjadi masalah dalam pengembangan UP2K umumnya hanya modal. Padahal banyak sekali sumber modal yang dapat digali, tetapi memang memerlukan laporan keuangan sebagai salah satu syarat pengajuannya.

Masalah tersebut juga dihadapi oleh UP2K di di Desa Mendalo Darat dan Mendalo Indah Kecamatan Jambi Luar Kota Kabupaten Muaro Jambi.UP2K di Desa Mendalo Darat sudah cukup aktif, namun perkembangannya masih lamban. UP2K di Desa Mendalo Indah belum terlalu aktif dalam melakukan pembinaan peningkatan ekonomi keluarga anggotanya. Berdasarkan informasi awal pada awal, pengurus yang sudah terbentuk menghadapi masalah yaitu salah satunya belum memahami terkait administrasi UP2K. Oleh karena itu, Tim Pengabdian Universitas Jambi tertarik untuk melakukan kegiatan pengabdian pada masyarakat dalam bentuk pembuatan aplikasi sederhana pengelolaan UP2K dan selanjutnya memberikan pembinaan Pengelolaan Keuangan pada pengurus UP2K kedua desa tersebut.

\subsection{Permasalahan Mitra}

Pemerintah Kabupaten Muaro Jambi memiliki geografis yang baik untuk pertanian dan perkebunan. Sebagian besar lahan pertanian dan perkebunan tersebut berada dalam wilayah 11 kecamatan yang terdiri dari 155 desa. Salah satu program yang terus dikembangkan oleh Tim PKK kedua desa tersebut adalah pengembangan UP2K. Salah satu kendala utama yang menyebabkan lambannya perkembangan UP2K adalah rendahnya akuntabilitas pengurus Kelompok UP2K. Hal ini dapat menurunkan kepercayaan anggota kepada pengurus.

Pengelolaan keuangan UP2K melingkupi administrasi keuangan Poksus, Administrasi keuangan Poklak, Laporan Pertanggungjawaban Periodik (Triwulan) dan Laporan Pertanggungjawaban Tahunan. Salah satu penyebabnya adalah masih kurangnya pemahaman Pengurus baik pada tingkat Poklak dan Poksus terkait hal tersebut. Pengelolaan keuangan yang baik akan meningkatkan akuntabilitas pengurus kepada anggota dan pihak yang berkepentingan. 


\section{METODE PELAKSANAAN}

Tahapan pelaksanaan kegiatan pengabdian ini terdiri dari tiga tahap yaitu:

\subsection{Tahap Perencanaan}

Tim peneliti melakukan survei dan koordinasi awal dengan mitra tentang rencana pengabdian yang akan dilakukan. Output dari kegiatan ini berupa persetujuan dalam bentuk pernyataan kesediaan kerja sama dari Mitra. Kegiatan Koordinasi awal ini dilakukan ke dua mitra pengabdian pada awal Januari 2018. Selanjutnya, tim pengabdian menyusun proposal pengabdian yang diusulkan ke LPPM Universitas Jambi. Setelah dinyatakan sebagai salah satu proposal yang diterima untuk dilaksanakan dan dibiayai dari alokasi dana PNBP Universitas Jambi untuk Skim Bina Desa, maka tim siap melakukan kegiatan pengabdian.

\subsection{Tahap Pelaksanaan}

Sebelum melaksanakan kegiatan pengabdian inti maka beberapa kegiatan telah dilakukan antara lain pembuatan aplikasi pengelolaan keuangan UP2K dan Koordinasi Tim ke Kepala Desa tanggal 20 April 2018 dan 23 April 2018. Koordinasi dilakukan juga dengan Camat Jambi Luar Kota dan Pengurus UP2K Kecamatan UP2K tanggal 23 April 2018. Koordinasi ke Ketua Tim Penggerak PKK Desa Mendalo Darat dilakukan tanggal 3 Agustus 2018 dan Mendalo Indah dtanggal 4 Agustus 2018. Berikut ini dokumentasi pelaksanaan koordinasi persiapan kegiatan pelatihan:

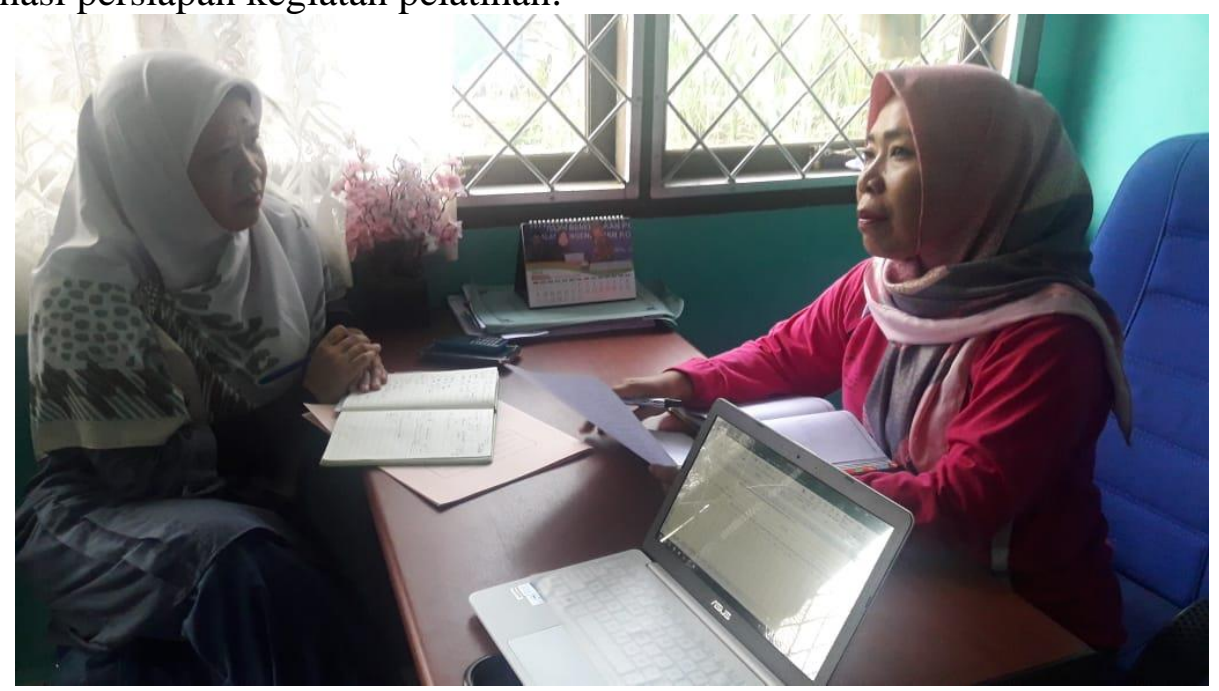

Gambar : Koordinasi dengan Sekretaris PKK Kecamatan Jambi Luar Kota sekaligus PJ Kepala Desa Mendalo Indah

Koordinasi dilakukan untuk penentuan jadwal dan teknis pelaksanaan pengabdian. Dari hasil koordinasi ditetapkan pelaksanaan kegiatan pembentukan di Mendalo Indah tanggal 06 September 2018 dan pelaksanaan pelatihan administrasi UP2K dilaksanakan tanggal 19-20 September 2018.

Selanjutnya tim melakukan survei identifikasi UMKM di Mendalo Indah. Berdasarkan dari data ini maka dilakukan Pembentukan UP2K Mendalo Indah secara formal.Metode pelaksanaan kegiatan menjelaskan tahapan dalam melaksanakan solusi yang ditawarkan untuk mengatasi masalah yang dihadapi kelompok UP2K Desa Mendalo Darat dan Desa Mendalo 
Indah Kabupaten Muaro Jambi. Adapun metode pelaksanaan kegiatan pengabdian ini adalah sebagai berikut:

a. Pihak-pihak yang terlibat dalam kegiatan pengabdian pada masyarakat ini yaitu para dosen dan mitra binaan dengan memperhatikan saran dari Tim Pengurus PKK Kabupaten Muaro Jambi.

b. Metode dan tahapan dalam kegiatan pengabdian pada masyarakat desa binaan ini , mulai dari identifikasi kebutuhan, perancangan sistem manual dan aplikasi, pembuatan, uji operasi aplikasi, pendampingan operasional, dan penerapan aplikasi sederhana pengelolaan keuangan Kelompok UP2K Desa Mendalo Darat dan Desa Mendalo Indah.

c. Aplikasi sistem informasi keuangan sederhana untuk mengelola dana UP2K Desa Mendalo Darat dan Desa Mendalo Indah menyediakan fitur dan format pengelolaan keuangan dana desa mulai dari Administrasi Keuangan Poksus, Poklak, Laporan Pertanggungjawaban Triwulan dan Tahunan.

d. Partisipasi mitra dalam pelaksanaan program.

e. Partisipasi mitra meliputi diskusi dengan dosen perguruan tinggi dan pemerintah desa dalam aktivitas berikut ini: survei penentuan tempat mitra binaan, penyusunan proposal, penentuan peserta untuk dilatih, pelatihan Administrasi Keuangan Poksus, Poklak, Laporan Pertanggungjawaban Triwulan dan Tahunan.

f. Evaluasi pelaksanaan program dan keberlanjutan program setelah selesai kegiatan.

\subsection{Tahap Pelaporan.}

Salah satu kewajiban dan output dari pelaksanaan kegiatan pengabdian ini adalah penyusunan laporan akhir dan artikel. Tim sedang dalam proses penyelesaian laporan akhir.

\section{HASIL DAN LUARAN YANG TELAH DICAPAI}

Luaran penelitian ini terdiri dari tiga yaitu aplikasi berbasis excel untuk pengelolaan keuangan UP2K, laporan akhir dan artikel pengabdian. Penggunaan basis excel sederhana mempertimbangkan kemudahan implementasi sehari-hari dalam kegiatan operasional pengurus UP2K, karena sebagian besar pengelola adalah Ibu-Ibu rumah tangga dengan kemampuan teknologi informasi masih perlu ditingkatkan. Dengan demikian, maka aplikasi sederhana yang sudah diberikan kepada pengurus, dapat digunakan secara berkelanjutan di UP2K. Hasil akhirnya akan meningkatkan akuntabilitas dan kepercayaan anggota UP2K.

Luaran yang telah tercapai adalah hasil inventarisasi para wanita yang yang menjalankan usaha sebagai UMKM di Desa Mendalo Indah dan Pembentukan UP2K Mendalo Indah dan Pembuatan. Pada saat penyusunan proposal pengabdian, informasi yang diterima dari Kepala Desa Mendalo Indah, telah memiliki kelompok UP2K aktif. Saat tim melakukan koordinasi awal sebelum pelaksanaan kegiatan pengabdian, kepala desa salah memahami tentang UP2K. Beliau menyamakan UP2K dan kegiatan PNPM. Oleh karena itu, tim melakukan koordinasi ke Pengurus PKK Kecamatan Jambi Luar Kota. Hasil koordinasi menunjukkan bahwa Desa Mendalo Indah merupakan salah satu desa di Kecamatan Jambi Luar Kota yang menjadi target untuk pembentukan UP2K tahun ini oleh Pengurus PKK Kecamatan Jambi Luar Kota.

Tim pengabdian melakukan survei di Desa Mendalo Indah untuk melakukan inventarisasi UMKM yang dikelola ibu-ibu sebagai calon anggota UP2K. Hasil Inventarisasi dan survei terdapat 20 orang ibu-ibu pengelola UMKM yang bersedia untuk bergabung 
dalam pembentukan UP2K Mendalo Indah. UMKM ini tersebar di 5 RT yaitu RT 19, RT 16, RT 04, RT 03 dan RT 05. Jenis usaha bervariasi mulai dari para pedagang sarapan pagi berupa lontong, nasi gemuk, penjahit, pembuat kue, usaha toko kelontong, toko sayur, pengusaha tempe, usaha kopi bubuk, usaha makanan ringan, salon dan laundry.

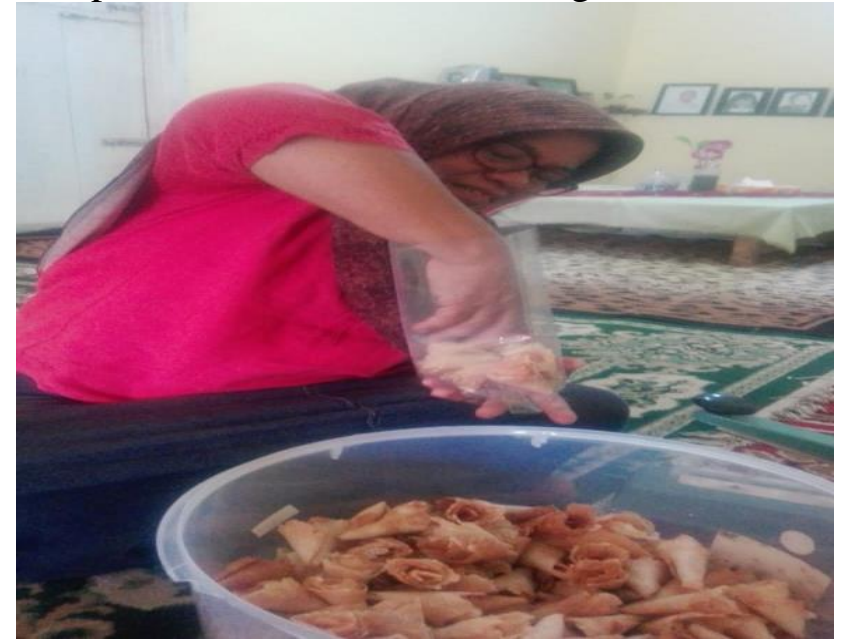

Gambar : Salah Satu hasil Produksi UP2K Desa Mendalo Indah

Kelompok UP2K Mendalo Indah yang telah dibentuk tanggal 06 September 2018, yaitu Poksus dan Poklak di Desa Mendalo Indah yang akan ditetapkan melalui Surat Keputusan Kepala Desa Mendalo Indah. PoksusMendalo Indah memiliki dua Poklak yaitu PoklakRaflesia yang terpusat di RT 05 dan Poklak Melati Suci yang terpusat di RT 04 (Daftar nama anggota terlampir). Pembentukan dilaksanakan di Rumah Ketua RT 05 Desa Mendalo Indah, yang dihadiri oleh calon anggota UP2K Kecamatan Mendalo Indah sebanyak 21 orang ibu-ibu yang memiliki aneka usaha.

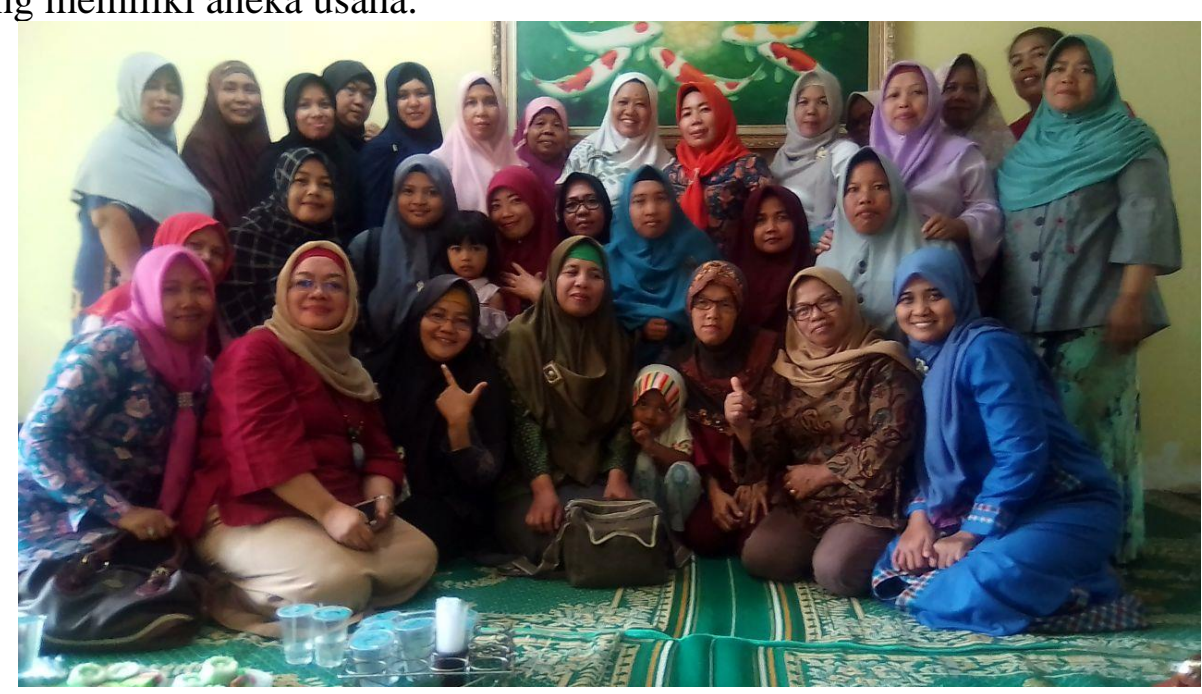

Gambar: Dokumentasi tim bersama pengurus UP2K dan beberapa Anggota UP2K Mendalo Indah

Pengurus Poksusdan Poklakjuga telah dibentuk berdasarkan hasil kesepakatan bersama. Kegiatan Pembentukan dihadiri juga oleh Kepala Desa Mendalo Indah, Ketua Tim PKK Desa Mendalo Indah, pengurus PKK Mendalo Indah dan Seluruh Anggota UP2K.

Pengelola UP2K terdiri dari Poksus yang berada ditingkat Desa/Kelurahan, Poksus UP2K PKK berada dibawahPokja 2 dengan susunan pengurus yang terdiri dari ketua, 
sekretaris dan bendahara. Pengurus Poksus ini bertugas melakukan pembinaan, pengawasan dan koordinasi terhadap poklak-poklak di desa tersebut. Secara rinci tugas Poksus yaitu:

1. Membimbing, mengarah, melayani dan mengawasi poklak-poklak termasuk pembentukan kelompok dan pemilihan pengurus kelompok pelaksana berdasarkan musyawarah dan mufakat

2. Membantu memecahkan maalah yang dihadapi poklak

3. Melaksanakan administrasi keuangan terhadap pengguna UP2K yang diberikan kepada poklak

4. Mengatur pemberian dana usaha kepada poklak

5. Menyampaikan laporan pelaksanaan perkembangan kegiatan UP2K kepada TP PKK desa/kelurahan

Poksus ini dibina dan diawasi oleh UP2K pada jenjang yang lebih tinggi.

Poklak yang merupakan ujung tombak UP2K merupakan kelompok yang terdiri dari keluarga-keluarga yang memilih usaha-usaha ekonomis produktif, setiap kelompok minimal terdiri dari 3-5 keluarga. Tugas Poklahteridir dari:

1. Memanfaatkan dana ang diterima dari Poksus untuk kegiatan usaha

2. Mengatur penyaluran dana usaha yang diterima

3. Menyampaikan iuran pengelolaan dan tabungan untuk pengembanan modal usaha kepada Poksus dan angsuran modal usaha yang diterima

4. Mematuhi kebijaksanaan dan ketentuan yang telah ditetapkan Polsus

5. Bertanggungjawab kepada Polsus dalam pengembangan modal usaha yang diterima

6. Membuat laporan perkembangan poklak

Perkembangan poklak harus menyajikan data sesuai kondisi yang sebenarnya dari kegiatan usaha keluarga yang dibina, beserta masalah dan solusi yang akan diambil.

Manajemen pengelolaan merupakan proses pengaturan pengelolaan dana UP2K PKK dari Poksus dan Poklak. Manajemen pengelolaan ini mencerminan proses yang berkaitan dengan berapa lamanya modal harus dikembalikan, berapa besar iuran dan simpanan yang harus dibayar oleh poklak dan siapa yang berhak menerimanya. Berdasarkan hasil diskusi di lapangan, tim menemukan kebijakan terkait manajemen pengelolaan yang dijalankan Poksus dan Poklak ditetapkan berdasarkan kesepakatan anggota-anggota UP2K.

Aplikasi pengelolaan keuangan UP2K telah dibuat oleh Tim berdasarkan hasil diskusi dengan Pengelola UP2K Kecamatan Jambi Luar Kota. Administrasi pengelolaan keuangan UP2K untuk Poklak dan Poksus meliputi:

1. Buku Kas (Buku 1)

2. Buku Pinjaman, angsuran, iuran, simpanan/tabungan (Buku 2)

3. Laporan/Tingkat Perkembangan UP2K (Buku 3)

4. Kartu Simpanan dan Pinjaman Anggota (untuk anggota)

Output dari administrasi ini merupakan pertanggungjawaban pengurus untuk disampaikan baik ke anggota UP2K maupun ke pengurus PKK ditingkat desa maupun kecamatan.

Pelatihan ini menggunakan dua metode pengelolaan pengelolaan keuangan UP2K yaitu metode manual dan metode berbasis komputer. Aplikasi pengelolaan keuangan berbasis excel yang dibuat oleh tim untuk dapat digunakan oleh pengurus, untuk membantu mempermudah pengelolaan keuangan UP2K. Basis excel dipilih agar dapat digunakan secara mudah oleh pengelola UP2K yang memiliki basis komputer terbatas.

Berikut contoh tampilan buku UP2K yang digunakan oleh Poksus dan Poklak: 


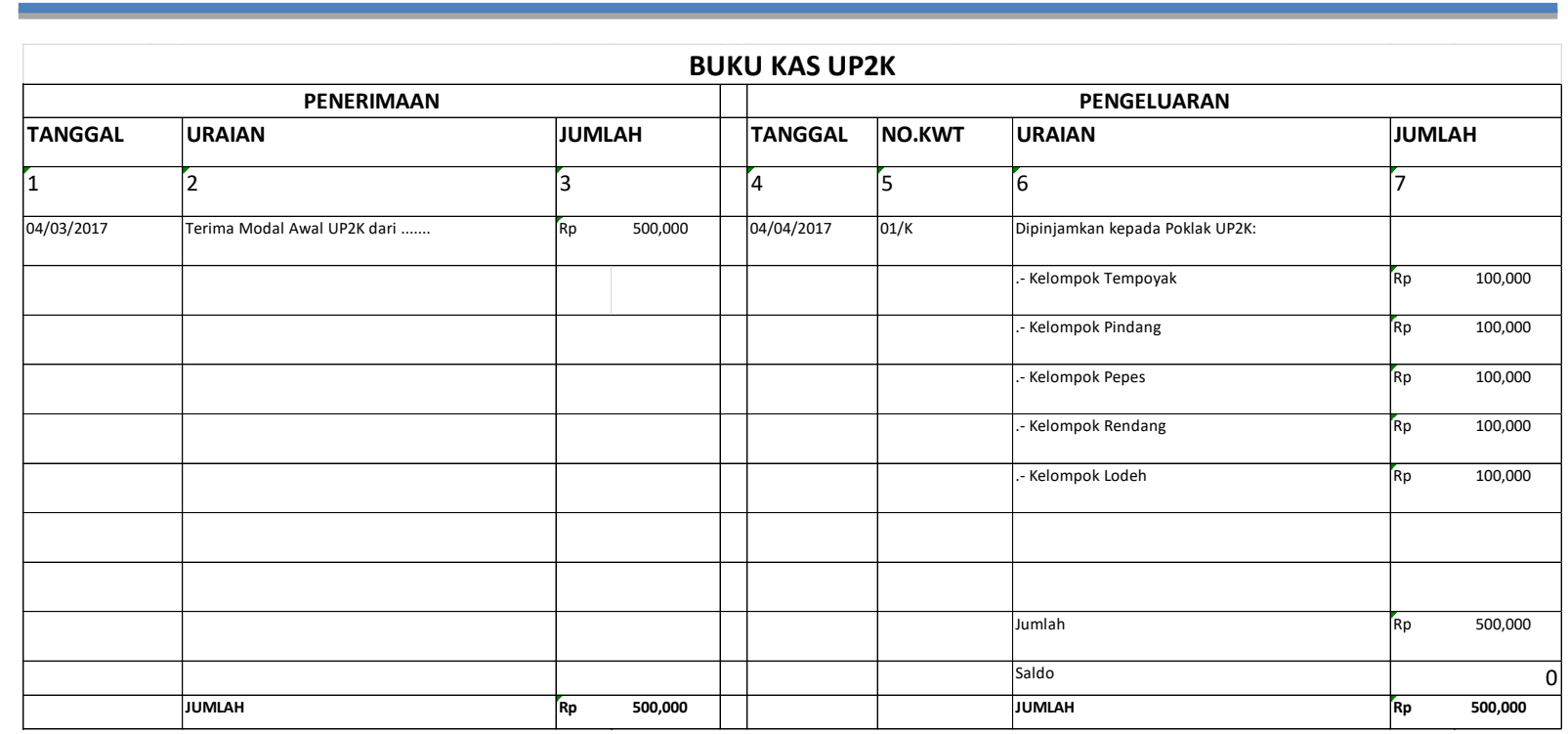

Contoh buku-buku UP2K yang lainnya dapat dilihat pada lampiran laporan ini.

Kegiatan pelatihan khusus bagi pengurus Poksus dan Poklak untuk Desa Mendalo Darat dan Mendalo Indah dilakukan pada tanggal 19 September 2018 di Balai Desa Mendalo Darat.

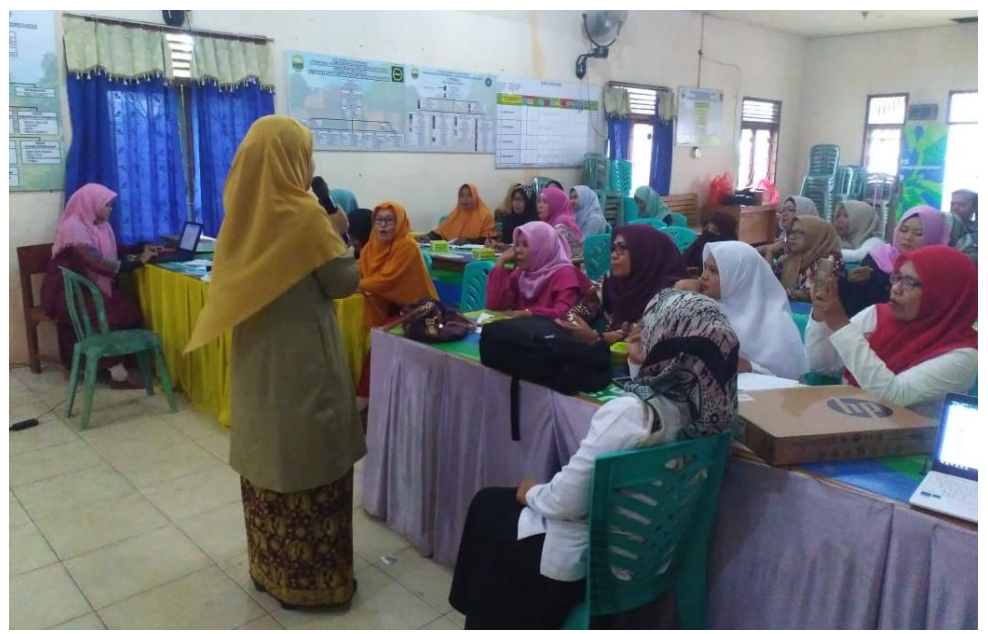

Gambar: Sesi Pemberian Materi oleh Ketua Tim

Kegiatan dibuka secara resmi oleh Kepala Desa Mendalo Darat. Selain Tim Penggerak PKK Desa dan pengurus Pokja II PKK Kecamatan Jambi Luar Kota.



Gambar: Penyajian Aplikasi UP2K Poksus berbasis Excel 
Peserta pelatihan ini adalah terdiri dari dua pengurus Poksus dan empat pengurus poklak dari kedua desa.

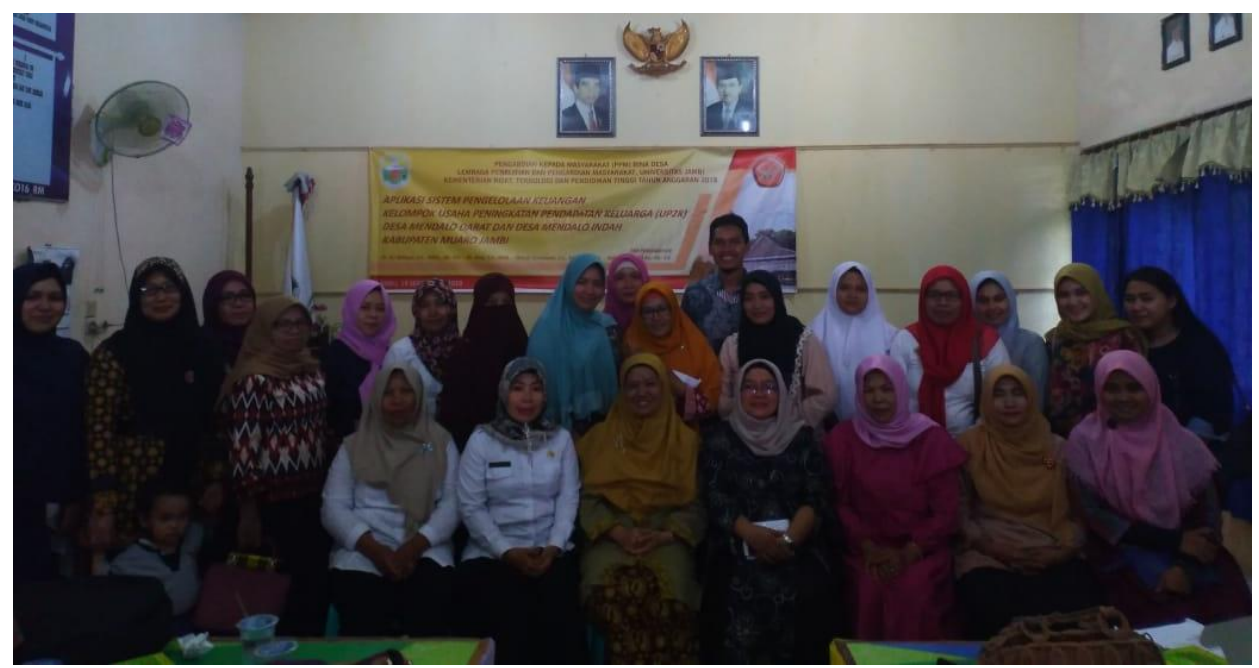

Gambar: Tim Pengabdian bersama sebagian pengurus UP2K

Materi kegiatan berupa pelatihan manual dan aplikasi excel untuk pengelolaan keuangan UP2K dan laporan pertanggungjawaban. Salah satu luaran terkait dengan publikasi pada media telah dilakukan oleh Tim. Kegiatan ini telah dipublikasikan di media on line dengan link http://jambi berita.com/read/2018/09/24/4168/dosen-unja-berikan-pelatihanadmistrasi-keuangan-ke-up2k-mendalo-darat-dan-mendalo-indah/.

\section{Kendala dan Upaya Meningkatkan UP2K}

Usaha Peningkatan Pendapatan Keluarga (UP2K) PKK di sini berfungsi untuk menumbuhkan kemampuan wiraswastakeluarga sebagai usaha memperluas lapangan kerja (Nursyahid dan Siswandi, 2015). Dalam pengembangan UP2K pengurus PKK memang harus ekstra sabar karena berhadapan dengan masyarakat bukanlah sesuatu yang mudah untuk dilakukan.

Poksus khususnya berperan memotivasi dan mendorong untuk mau secara berkelompok dalam mengembangkan usaha. Tujuannya untuk mempermudah melakukan proses bimbingan, pembinaan, evaluasi dan pengawasan. Dari hasil wawancara dan diskusi di lapangan, tim menemukan beberapa kendala yang sering dihadapi oleh Pokja II dan Poksus dalam melaksanakan tugasnya antara lain:

1. Data UMKM khususnya yang dijalankan oleh Ibu-Ibu dan keluarga lainnya belum tersedia dengan baik. Nursyahid dan Siswandi(2015), menyatakan peningkatan Pendapatan Keluarga (UP2K) dibutuhkan data yang valid tiap Kepala Keluarga(KK).

2. Kemampuan Sumber Daya Manusia (SDM) yaitu TimPenggerak PKK dan Kader. Rendahnya kemampuan SDM desa ditemukan bukan hanya untuk kader PKK namun juga untuk perangkat desa (Thomas, 2013). Padahal SDM yang berkompeten menjadi basis pembangunan di daerah (Huda, 2011). Oleh karena itu, pemerintah kabupaten, kecamatan dan desa bukan hanya memperhatikan peningkatan kualitas SDM aparatur negara saja, tetapi juga termasuk para pengurus PKK umumnya dan UP2K khususnya.

3. Anggaran masih terbatas. Masalah klasik yang selalu dihadapi oleh UMKM dan sebagian besar Kelompok UP2K di Indonesia adalah UP2K. Peraturan Menteri Dalam Negeri Nomor 113 Tahun 2014 tentang Pedoman Pengelolaan Keuangan Desa yang 
kemudian diturunkan oleh Pemerintah Daerah Kabupaten Muaro Jambi dalam bentuk Peraturan Bupati Nomor 16 Tahun 2016 Tentang Tata Cara Pembagian dan tata Cara Penetapan Rincian ADD setiap desa Kabupaten Muaro Jambi Tahun 2016 tidak mengizinkan Desa memberikan bantuan untuk UP2K dalam bentuk uang tunai. Berdasarkan penjelasan dari Ketua TP PKK Mendalo Darat ini menjadi salah satu kendala untuk mengembangkan usaha UP2K, karena dana yang terbatas membuat bantuan untuk usaha juga terbatas. Desa dapat memberikan bantuan bagi UP2K dalam bentuk barang yang digunakan untuk meningkatkan keterampilan anggota UP2K. Keterbatasan anggaran menjadi salah satu faktor utama lambannya perkembangan UP2K desa (Nursyahid dan Siswandi, 2015). Penganggaran dana desa memang harus memperhatikan bagaimana distribusi dan di mana akan didistribusikan, karena subsidi dapat mempengaruhi pengeluaran publik (Adrian, 2001).

Upaya yang dapat dilakukan dalam mengembangkan UP2K antara lain telah dilakukan oleh Tim Penggerak PKK Pusat dengan menetapkan beberapa sasaran pengembangan kehidupan berkoperasi yang merupakah hasil rapat kerja Nasional PKK KE VIII Tahun 2015, yang dilakukan oleh kelompok kerja (Pokja) II PKK pada seluruh jenjang yaitu sebagai berikut:

a) Penguatan/pengembanganKelompok-kelompok UP2K-PKK

b) Meningkatkan Sumberdaya Manusia/Pengelola program UP2K-PKK dalamupaya pengembangan programUP2K-PKK.

c) Pengembangan pemasaran hasilproduksi UP2K-PKK melalui Pamerandan kemitraan dengan Kementeriandan lembaga serta instansi terkait.

d) Mengembangkan kreatifitas Usaha Mikro Kecil dalam upayapeningkatan produktifitas danekonomi Keluarga.

e) Mendorong Poksus UP2K-PKK agarmembentuk koperasi yang berbadanhukum.

f) Memotivasi keluarga agar tahu,mau, dan mampu menjadi anggotakoperasi untuk meningkatkanekonomi keluarga.

Sasaran tersebut merupakan penjabaran dari 10 Program PKK yang terkait dengan tugas Pokja 2 yaitu Pemberianketerampilan keluarga dalam upaya peningkatandan pemberdayaan ekonomi keluarga melaluipengembangan ekonomi kreatif dan Usaha MikroKecil, serta pengembangan kehidupanberkoperasi.

Upaya lainnya yang dapat dilakukan antara lain:

1. Poksus dapat mengembangkan modal melalui kerja sama dengan lembaga keuangan yang ada.

2. Perlu identifikasi data base UMKM desa yang baik, sehingga mudah melakukan pembinaan dan pengawasan serta penggembangan usaha.

3. Mendorong partisipasi seluruh warga dapat diwujudkan apabila terdapat transaparansi yang baik dalam kebijakan yang ditetapkan (Rahayu, 2010).

4. Transparansi dan akuntabilitas pengelolaan dana desa akan meningkatkan kepercayaan masyarakat kepada perangkat desa (Sujarweni, 2015) termasuk dana UP2K.

Upaya-upaya yang dilakukan secara optimal akan dapat meningkatkan ekonomi masyarakat melalui UP2K. Hal ini sesuai dengan amanat UU No 6 Tahun 2014 tentang Desa, bahwa kepala desa memiliki tugas untuk mengembangkan perekonomian masyarakat desa, yang dapat dilakukan melalui pengembangan usaha Ibu-Ibu yang dibina oleh PKK Desa. 


\section{KESIMPULAN DAN SARAN 4.1.Kesimpulan}

Kegiatan pengabdian pada masyarakat ini telah dapat dilaksanakan dengan baik dan lancar. Proses pengelolaan keuangan UP2K sebagai organisasi pra koperasi yang membina para pengusaha UMKM wanita belum banyak menjadi perhatian khususnya bagi para akademisi. Peserta begitu antusias dalam proses diskusi, banyak topik di luar pengelolaan dana UP2K juga menjadi menjadi pertanyaan peserta, khususnya berkaitan dengan strategi pengelolaan usaha yang baik. Tahapan kegiatan pengabdian ini terdiri dari tahapan perencanaan dan tahapan pelaksanaan serta tahapan pelaporan.

\subsection{Saran}

Berdasarkan proses pengabdian yang telah dilaksanakan, maka sebaiknya pengelolaan keuangan UP2K menjadi salah satu target yang harus dibina secara berjenjang oleh pemerintah daerah melalui PKK mulai dari tingkat desa sampai dengan PKK Kabupaten/Kota. Selain itu keterlibatan akademisi perguruan tinggi dapat mempercepat proses peningkatan administrasi keuangan UP2K. Pengelolaan dana UP2K yang baik menjadi bagian dari usaha meningkatkan tata kelola keuangan desa.

\section{DAFTAR PUSTAKA}

Baron, R. A dan DonnByrne. 2003. Psikologi Sosial. Jakarta: Erlangga

Fozzard, Adrian. 2001. The basic budgeting problem: Approachesto Resources allocation in the public sector and their implications for pro - poorbudgeting. Center for Aid and Public Expenditure, Overseas Development Institue (ODI). Working Paper 147.

Halim, A \& Abdullah, S. 2006. Hubungan dan Masalah Keagenan di Pemerintah Daerah: Sebuah Peluang Penelitian Anggaran dan Akuntansi. Jurnal Akuntansi Pemerintah, Vol. 2.

Huda, S, 2011, Pengelolaan Sumber Daya Manusia Kompeten sebagai Basis Pembangunan Daerah, Media Akademika, Vol. 26, No. 3, Juli

Bastian, I. 2015. Akuntansi untuk Kecamatan dan Desa. Salemba 4. Jakarta.

Nursyahid, Arif dan Andre Siswadi, 2015, Sistem Informasi Usaha Peningkatan Pendapatan Keluarga (UP2K) Secara Online Di Kelurahan Bulusan KecamatanTembalang. JURNAL TELE Volume 13 Nomor 2 Edisi Oktober

Peraturan Menteri Dalam Negeri Nomor 113 Tahun 2014 tentang Pedoman Pengelolaan Keuangan Desa.

Peraturan Bupati Nomor 16 Tahun 2016 Tentang Tata Cara Pembagian dan tata Cara Penetapan Rincian ADD setiap desa Kabupaten Muaro Jambi Tahun 2016.

Rahayu, S. 2010. Persepsi Pemerintah Daerah Kota Jambi Terhadap Partisipasi Masyarakat Dan Transparansi Kebijakan Publik Dalam Penyusunan Anggaran Pendapatan Dan 
Belanja Daerah. Jurnal Penelitian Universitas Jambi Seri Humaniora ,Volume 12, Nomor 2, Juli - Desember. Hal. 29-34

Sujarweni, Wiratna. 2015. Akuntansi Desa: Panduan Tata Kelola Keuangan Desa. Pustaka Baru. Yogyakarta.

Thomas, 2013, Pengelolaan Alokasi Dana Desa Dalam Upaya Meningkatkan Pembangunan Di Desa Sebawang Kecamatan Sesayap Kabupaten Tana Tidung, Ejournal Pemerintahan Integratif.

Undang-Undang No. 6 Tahun 2014 tentang Desa 